\title{
Emerging Trend in Therapeutic Potential of Casein Derived Bioactive Peptides
}

\author{
Lalita Garg $^{1 *}$ and Kamal Kumar ${ }^{2}$ \\ ${ }^{1}$ Division of Livestock Products Technology, ${ }^{2}$ Division of Extension Education, ICAR-Indian \\ Veterinary Research Institute, Izatnagar, Bareilly, U.P., India \\ *Corresponding author
}

\section{A B S T R A C T}

\begin{tabular}{|l|}
\hline Keyw or d s \\
Casein, Bioactive \\
Peptides
\end{tabular}

Casein is a high biological value protein due to high indispensable amino acid and protein digested corrected amino acid score. Bioactive peptides enchanted many activities, such as immunoregulatory, Opioid, etc. These peptides usually consist of 2-20 amino acids and become activated after release from inherent protein following enzymatic hydrolysis either in vivo or in vitro. The most common method to produce bioactive peptides is enzymatic proteolysis of the parent protein. Casein-derived bioactive peptides possess antioxidant, antihypertensive, antidiabetic, antithrombotic, and antimicrobial activity. Nowadays, due to the increasing demand for functional foods and nutraceuticals by consumers, bioactive peptides are incorporate into food to enhance their functionality.

\section{Introduction}

Milk is an excellent source of protein with multiple therapeutic properties on health. It consists of two types of protein; one is a soluble protein known as whey protein that accounts for $20 \%$, whereas another fraction consists of an insoluble protein known as casein, which constitutes $80 \%$ of total milk protein (Haug et al., 2007; Severin and Wenshui, 2005). Casein consists of four fractions, namely $\alpha \mathrm{s} 1, \alpha \mathrm{s} 2, \beta$, and $\kappa$-casein (Fox et al., 1998). Casein is a high biological value protein due to high indispensable amino acid and protein digested corrected amino acid score (Boye et al., 2012; Schaafsma, 2000). Bioactive peptides enchanted many activities, such as immunoregulatory, opioid, antioxidant, antihypertensive, antidiabetic, etc. Significant studies have done on the casein derived bioactive peptides. These peptides usually consist of 2-20 amino acids and become activated after release from inherent protein following enzymatic hydrolysis either in vivo or in vitro. The significant difference between drugs and bioactive peptides is that synthetic drugs are administered intentionally within the body, on the other hand, bioactive peptides may be present in humans as they may arise from the digestion of food. Examples of casein-derived bioactive peptides constitute casein phosphopeptides (CPPs) (k-casein, f(147153)) that helps in transportation and 
absorption of specific minerals (FitzGerald, 1998); glycomacropeptides (GMP) that bind toxins (Kawasaki et al.,1992); isracidin (as1casein, $\mathrm{f}(1-23)$ ) that possesses immunomodulatory effects (Lahov \& Regelson, 1996); and casoxins (k-casein, $\mathrm{f}(58-61))$ that behave as opioid antagonists (Chiba et al., 1989; Xu, 1998) while casomorphins (as1-casein, f(90- 95); ArgTyr-Leu-Gly-Tyr-Leu) may behave as opioid receptor agonists (Loukas et al., 1983; Teschemacher, 2003).

\section{Bioactive peptides}

Bioactive peptides are the chains of 2-20 amino acid sequence (Korhonen and Pihlanto, 2006), encrypted within the native protein sequence. These peptides are inactive within the parent protein but get activated when cleaved from the parent chain and show biological activity. These can be produced in vivo by gastrointestinal enzymes and in vitro by specific enzymes (Miguel et al., 2009).

Functionally bioactive peptides released from parent protein in the following ways:

Enzymatic hydrolysis by digestive enzymes (Kilara and Panyam, 2003; Korhonen and Pihlanto, 2003).

Fermentation of milk with the proteolytic starter culture (Fuglsang et al., 2003).

Gastrointestinal digestion (Ferranti et al., 2004).

\section{Enzymatic hydrolysis}

The most common method to produce bioactive peptides is enzymatic proteolysis of the parent protein. Pepsin and trypsin are the two most common enzymes used for proteolysis (Ferreira et al., 2007). Pepsin, chymotrypsin, alcalase, thermolysin, pancreatin, and multiple enzymes of different origin, and their combinations could be used, to produce bioactive peptides having an antioxidant, antimicrobial, antihypertensive, and antidiabetic activity (Kilara and Panyam, 2003).

\section{Microbial fermentation}

Many starter cultures have been used to hydrolyze the protein especially casein. Cultures like Lactococcus lactis, Lactobacillus delbrueckii ssp. bulgaricus and Lactobacillus helveticus possess cell wallbound protease and peptidases like dipeptidases, tripeptidases, aminopeptidases, and endopeptidases (Griffiths and Tellez, 2013). Lactococcus helveticus was highly proteolytic and the most commonly used starter culture in fermented dairy products (Szwajkowska et al., 2011). Two renowned antihypertensive peptides, Val-Pro-Pro and Ile-Pro-Pro were isolated from fermented milk of Lactococcus helveticus (FitzGerald et al., 2004). Ashar and Chand (2004) identified an antihypertensive peptide from fermented milk. The identified fragment had an amino acid sequence Ser-Lys-Val-Tyr-Pro-Phe-ProGly Pro-Ile that showed it was a part of $\beta$ casein. Tryptic and peptic casein hydrolysates triggers in vitro immunomodulatory effect on human blood lymphocytes. Moreover, bioactive peptides released by microbial enzymes could be attacked by other enzymes present in GIT and produce some other peptides (Shimizu and Ok Son, 2007; Moller et al., 2008).

\section{Gastrointestinal digestion}

Numbers of functional peptides are released, during gastrointestinal digestion in the body (Ferranti et al., 2004). After ingestion, food protein undergoes denaturation and assimilation by several proteolytic enzymes e.g. pepsin, trypsin, and chymotrypsin to produce functional peptides. Peptidase like carboxypeptidase, aminopeptidase, act further 
on peptides and convert them into amino acids for absorption. For example, $\beta$ casomorphins and casein phosphopeptide (CPP) discharges in the gastrointestinal tract following oral consumption of dairy products (Hernandez-Ledesma et al., 2004).

\section{Bioactive peptides used in the dairy industry}

Nowadays, due to the increasing demand for functional foods and nutraceuticals by consumers, bioactive peptides are incorporated in food to enhance their functionality. Sugai (1998) reported a product "casein DP peptio drink" made up of casein hydrolyzed with trypsin. $20 \mathrm{~g}$ of tryptic casein hydrolysate for 4 weeks resulted in lowering of blood pressure in hypertensive patients (Sekiya et al., 1992). Another product named "C12 Peption" in the Netherlands made up of tryptic hydrolyzed casein, prescribed in hypertensive animals and humans to control the blood pressure (Cadee et al., 2007; Karaki et al., 1990). Calpis, fermented milk, cultured by using Saccharomyces cerevisiae and Lactobacillus helveticus, contained two wellknown ACE inhibitory peptides, Val-Pro-Pro (VPP) and Ile-Pro-Pro (IPP) from $\beta$-casein and $\kappa$-casein, respectively (Nakamura et al., 1995). The number of commercial dairy products from different countries with health claims has shown in Table. 1.

\section{Antioxidant activity}

Oxidative metabolism is one of the primary functions for cell maintenance while, failure in metabolism generates several reactive oxygen species (ROS) and free radicals, inducing oxidative stress. Free radicals like peroxide radical, hydroxyl radical, superoxide radical, and hydrogen peroxide are ordinarily known as ROS, not only cause food spoilage, also harmful to biological systems. Certain free radical species like peroxidase, catalase, and superoxide dismutase have a damaging effect on endogenous defensive enzymes (Fang et al., 2002). These enzymes damage and prompt deadly cellular outcomes (e.g., apoptosis) by oxidation of cellular proteins, lipids in the membrane, enzymes, and DNA (Harvey and Ferrier, 2011). These free radical species may additionally produce alterations at the cellular level that drive several human ailments like arthritis, hypertension, atherosclerosis, and cancer (Frenkel, 1992).

Ahmed et al., (2015) reported the antioxidant activity of both casein and whey protein hydrolysate from goat milk. Pepsin-digested goat casein protein (P-GCP) and pepsin digested goat whey protein (P-GWP) showed remarkably high superoxide and DPPH radical scavenging activity as compared to the GCP and GWP. The hydrolysates of goat milk whey and casein fractions contain peptides, which acts as electron donors that could reduce the free DPPH radicals into stable molecules. Various bioactive peptides possessing antioxidant activity were e.g. $\alpha$ s2casein $\mathrm{f}(82-88)$, $\alpha \mathrm{s} 2$-casein $\mathrm{f}(141-148), \beta$ casein $\mathrm{f}(124-137), \quad \kappa$-casein $\mathrm{f}(61-70)$, lactoferrin $\mathrm{f}(33-43), \beta$-lactoglobulin $\mathrm{f}(38-48)$ and $\beta$-lactoglobulin $\mathrm{f}(113-122)$. Bioactive peptides having Leu residues and the SerLeu/Thr-Leu/Pro-Leu motifs in their sequences, particularly at $\mathrm{N}$ and C-terminus, seemed to have superior scavenging activities. Chen et al., (1996) reported a peptide from casein, Pro-His-His that showed maximum antioxidant activity. Bioactive peptides having His were associated with hydrogendonating ability, lipid peroxy-radical trapping, and metal ion chelating ability. Bovine casein hydrolyzed with trypsin alone and with a combination of pepsin and trypsin showed antioxidant activity. Tryptic hydrolysate showed maximum antioxidant activity $(13.7 \%)$ at $4 \mathrm{hr}$ of digestion. The casein hydrolysate was fraction into $10 \mathrm{kDa}$ and 1 $\mathrm{kDa}$ through ultrafiltration. Crude 
hydrolysates and the permeates from $10 \mathrm{kDa}$ and $1 \mathrm{kDa}$ showed radical scavenging activity $13.7 \%$, $17.3 \%$, and $24.4 \%$, respectively (Irshad et al., 2015). Shanmugam et al., (2015) scrutinized the antioxidant activity of buffalo casein hydrolyzed with pepsin, trypsin, and chymotrypsin alone and in combinations. He found that Pepsin-trypsin digested hydrolysates showed higher antioxidative action than other hydrolysates. Kumar et al., (2016) studied that $\alpha$ chymotrypsin produced significantly higher DH and antioxidant activity than alcalase and papain. Nongonierma and FitzGerald (2013) reported that tryptophan was a better scavenger of DPPH radical than valine. Suetsuna and Chen (2002) stated antioxidant activity of peptides depends on the $\mathrm{C}$ or $\mathrm{N}$ terminal position of amino acid residues. For example, Trp-Lys has a more robust antioxidant action than Lys-Trp. Table. 2 showing the antioxidant peptides derived from casein.

\section{Antihypertensive activity}

Hypertension is also known as high blood pressure. Cardiovascular disease (CVD) is the number one cause of death globally, and 17.9 million people died due to CVD in 2016, representing $31 \%$ of global death (WHO, 2017). Different interacting biochemical pathways such as the renin-angiotensin system control the risk of CVD (Sultan et al., 2018). In clinical practice, vasodilators, diuretics, calcium channel blockers, angiotensin II receptor blockers, and angiotensin I-converting enzyme (ACE) inhibitors, applied to control blood pressure. These substances interfere with the different interacting biochemical pathways that control blood pressure, specifically the reninangiotensin system, the kinin-kallikrein system, the neutral endopeptidases system, and the endothelin-converting enzyme system (FitzGerald et al., 2004). The dipeptidyl carboxypeptidase enzyme (ACE) catalyzes, the production of vasoconstrictor i.e. angiotensin II on one side and inactivation of vasodilator i.e. bradykinin on another side, hence involved in both renin-angiotensin system and kinin-kallikrein system. Thus ACE blockers played a significant role in the regulation of blood pressure. Despite, the side effects of synthetic ACE inhibitors such as hypotension, cough, increased potassium levels, decreased kidney function, angioedema, they are used extensively in hypertension (FitzGerald et al., 2004). This stimulates our interest in finding natural ACE inhibitors. The natural ACE inhibitor was first time identified in snake venom (Ondetti et al., 1977). The number of bioactive peptides isolated from the milk (Meisel, 2004), gelatine (Oshima et al., 1979), maize, soybean (Chen et al., 1996) that inhibit ACE. Casokinins and lactokinins from casein and whey protein showed ACE inhibitory property (Kitts and Weiler, 2003). The presence of aromatic or branched-chain amino acids such as tyrosine, phenylalanine, proline, and lysine at the $\mathrm{C}$-terminal positions of a peptide enhances the binding of the substrate with the enzyme. The ACE enzyme is present in the lung, kidney, heart, skeletal muscle, arteries, testes, uterus, brain, and epithelial cells of the jejunum (Ondetti and Cushman, 1982).

Mao et al., (2007) reported that yak milk casein hydrolysate obtained at $4 \mathrm{~h}$ of hydrolysis showed maximum ACE inhibitory activity. Furthermore, identified two novel peptides, Pro-Pro-Glu-Ile-Asn (PPEIN) and Pro-Leu-Pro-Leu-Leu (PLPLL) from $\kappa$ casein and $\beta$-casein, respectively. The molecular weight and IC50 value of the peptides were $550 \mathrm{Da}, 566.4 \mathrm{Da}$ and $0.29 \pm$ $0.01 \mathrm{mg} / \mathrm{ml}, 0.25 \pm 0.01 \mathrm{mg} / \mathrm{ml}$ respectively. Perpetuo et al., (2003) identified a peptide Tyr-Pro-Val-Glu-Pro-Phe-Thr-Glu from tryptic casein hydrolysates that exhibited 
ACE inhibitory activity. Otte et al., (2007) elucidated lower activity of the A1 than the A2 variant of $\beta$-casein on digestion with trypsin. Some di-peptides, tri-peptides and longer chain peptides such as Tyr-Gln-GluPro, Val-Pro-Lys-Val-Lys, Pro-Leu-Pro-LeuLeu, His-Leu-Pro-Leu-Pro, Tyr-Gln-Glu-ProVal-Leu-Gly-Pro and Ser-Leu-Val-Tyr-ProPhe-Pro-Gly-Pro-Ile from $\beta$-casein, Tyr-Pro, Arg-Pro-Lys and Arg-Pro-Lys-His-Pro-IleLys-His from as1-casein and Pro-Pro-Glu-IleAsn from $\kappa$-casein showed ACE-inhibitory activity (Ashar and Chand, 2004; HernandezLedesma et al., 2007; Yamamoto et al., 1999). Peptides derived from casein correspond to the fraction (23-24), (23-27) and (194-199) of bovine as1-casein, as well as fraction (177-183) and (193-202) of bovine $\beta$-casein showed ACE inhibitory activity (Maruyama and Suzuki, 1982). Karaki et al., (1990) observed a significant decrease in blood pressure after oral administration of tryptic casein hydrolysate in spontaneously hypertensive rats. Camel whole milk casein and $\beta$-casein were digested with pepsin, trypsin, and chymotrypsin. Hydrolysate fraction showed higher ACE inhibitory activity compared with an unhydrolyzed fraction (Salami et al., 2011). Miguel et al., (2009) investigated both in vivo and in vitro effect of bovine casein hydrolysates (HBC) on blood pressure. In vitro study of $\mathrm{HBC}$ and $\mathrm{HBC},<3 \mathrm{kDa}$ showed an IC50 value of 52 $\mu \mathrm{g} / \mathrm{ml}$ and $5.5 \mu \mathrm{g} / \mathrm{ml}$, respectively. In vivo study showed a significant decrease in both systolic and diastolic blood pressure when $\mathrm{HBC}$ and $\mathrm{HBC}<3 \mathrm{kDa}$ administered in spontaneously hypertensive rats. LopezExposito et al., (2007) identified two chemically synthesized peptides, LKKISQ and PYVRYL from, ovine as2-casein that exerted potent ACE inhibitory activity. PetratMelin et al., (2015) reported maximum ACE inhibition in the A1 and B variant as compared to the A2 and I variant of $\beta$-casein hydrolyzed with pepsin and pancreatic enzyme. Garg et al., (2021) reported Both A1 and A2 casein hydrolysates manifested ACE inhibition, whereas improved activity was recorded with progress in time and degree of hydrolysis.

\section{Antidiabetic activity}

Diabetes is a chronic disease that occurs either not secretion of insulin from the pancreas or the body cannot effectively utilize the insulin that it produces. It leads to severe damage to many organs and the major cause of blindness, kidney failure, heart attack, stroke, and lower limb amputation (WHO, 2016). So, effective management of diabetes is the principal concern. Diabetes mellitus (DM) is of two types: type $1 \mathrm{DM}$ is also known as insulin-dependent or juvenile or childhood-onset diabetes, owing to the damage of $\beta$ cells of the pancreas and requires daily administration of insulin. Type $2 \mathrm{DM}$ is also known as non-insulin-dependent or adultonset diabetes that occurs when the body becomes resistant to insulin or does not make enough insulin. Type $2 \mathrm{DM}$ is the most common type of diabetes in the world and the result of physical inactivity and obesity (WHO, 2016). According to the WHO global report on diabetes, the number of people has almost quadrupled since 1980 to 422 million adults. The dramatic rise is only due to the surge in type 2 DM. In 2012, diabetes caused 1.5 million deaths. This report calls upon governments to ensure that people can make healthy choices and that health systems can diagnose, treat and care for people with diabetes. It encourages all individuals to eat healthily, be physically active and avoid excessive weight gain (WHO, 2016). People with type 2 diabetes need to make a healthy diet plan (choose low sugar and low-fat food) and exercise daily. Type 2 diabetes accounts for about $90 \%$ of cases diagnosed. It is a principal cause of mortality, accounting for $14.5 \%$ of global mortality among adults aged 
20 to 79 (International Diabetes Federation (IDF), 2015). IDF estimated that currently, 415 million people ( 1 in 11 adults) suffering from diabetes, and predicts that, if the present demographic growth continues, 642 million ( 1 in 10 adults) will be affected by this metabolic disorder by 2040. India is one of the six countries of the IDF Southeast Asian (SEA) region. Globally, 425 million people have diabetes, and 82 million people live in SEA Region; by 2045, this will rise to 151 million. There were over $72,946,400$ cases of diabetes in India in 2017. Casein protein supplementation to high carbohydratecontaining meals leads to a reduction in postprandial blood glucose levels and an increase in plasma insulin concentrations in healthy and diabetic individuals. Exclusively the release of bioactive peptides upon digestion of whey protein was responsible for antidiabetic activity (Jakubowicz and Froy, 2013).

$\alpha$-glucosidase is present in the brush border of the small intestine and transforming the oligosaccharides and disaccharides into monosaccharides, thus facilitates the glucose absorption process (Matsui et al., 1996). Curtailing the action of $\alpha$-glucosidase is considered to be an effective strategy to control postprandial blood glucose levels. Some synthetic compounds such as acarbose, miglitol, and voglibose possess $\alpha$-glucosidase inhibitory activity. Ghamari et al., (2013) studied the $\alpha$-glucosidase inhibitory activity of aloin with and without $\beta$-casein and observed that aloin was a potent inhibitor. In vitro antidiabetic effect of curd supplemented with Aloe gel (AG) powder demonstrated $\alpha$ glucosidase inhibitory activity. Curd with different concentrations of AG- 0.15AG, $0.20 \mathrm{AG}$, and $0.25 \mathrm{AG}$ showed $30.7 \%, 40.1 \%$, and $43.6 \%$ greater inhibition as compared to plain curd (Ramachandran and Srividya, 2014). $\alpha$-amylase is an enzyme that breaks down the polysaccharides like starch into maltose and glucose. Reducing the starch hydrolysis by inhibiting the pancreatic $\alpha$ amylase enzyme is an effective approach to control type 2 DM (Pinto et al., 2009) because it delays the hydrolysis and reduces the availability of glucose in the blood, resulting in the reduction of postprandial blood glucose level (Ali et al., 2006). One of the disadvantages of this strategy is that excessive inhibition leads to bloating, flatulence, and other digestive issues (Kwon et al., 2006). Raw and boiled sheep milk casein was hydrolyzed with pepsin, trypsin, and chymotrypsin and showed higher $\alpha$ amylase inhibition. Chymotrypsin treatment showed maximum $\alpha$-amylase inhibitory activity as compared to pepsin and trypsin. Peptides from boiled milk casein show reduced antidiabetic properties. Therefore, raw milk casein hydrolysates may be used as nutritional supplements for diabetic patients, as it causes significant inhibition of $\alpha$-amylase (Jan et al., 2016).

\section{Antithrombotic activity}

Blood clotting is a multifaceted physiological process regulated by a sequence of proteolytic reactions with extensive interactions (Davie $e t$ al., 1991; Furie \& Furie, 1988). During blood clotting, prothrombin gets converted to thrombin by proteolytic degradation (Bode, 2006). The principal purpose of thrombin is to transform soluble fibrinogen into insoluble fibrin and catalyze a chain of responses linked to blood coagulation. Thus the inhibitory activity of any bioactive agents against thrombin is supposed to be a pointer of antithrombotic activity. Food-derived constituents such as peptides may be suitable nominees for antithrombotic activity because of their least side effects. Food proteins can be perceived as antecedents of bioactive peptides (Shahidi \& Zhong, 2008). Milk clotting proteins like chymosin and kappa casein, share similar mechanism like blood 
clotting mechanism that involves thrombin and fibrinogen (Erdmann et al., 2008). Peptides derived from $\kappa$-casein hydrolysates demonstrated antithrombotic activity preventing fibrinogen binding platelet (Schlimme and Meisel, 1995). These peptides are released during gastrointestinal digestion and get absorbed into the bloodstream, this mechanism supports the fact of in vivo antithrombotic activity. $\kappa$-casein hydrolysates exhibited multifunctional roles like ACE inhibitory and antithrombotic. $\kappa$-casein fraction (106-116), illustrated anticoagulant activity, similar to the amino acid sequence to decapeptide from the fibrinogen Gammachain (fragment 400-411) (Tu et al., 2017). Sheep caseins derived $\kappa$-caseinoglycopeptide (106-171) reduced thrombin and collageninduced platelet aggregation in a dose dependent manner (Qian et al., 1995).

Table.1 Commercial dairy products and ingredients with health claims based on bioactive peptides (Adapted from: Korhonen and Pihlanto, 2006)

\begin{tabular}{|c|c|c|c|}
\hline Brand name & Bioactive peptide & Health claims & Country \\
\hline Evolus & $\begin{array}{l}\text { VPP, IPP from } \beta \text {-casein } \\
\text { and k-casein in calcium } \\
\text { enriched fermented milk }\end{array}$ & $\begin{array}{l}\text { Blood pressure } \\
\text { reduction }\end{array}$ & Finland \\
\hline Biozate & $\begin{array}{l}\beta \text {-lactoglobulin from } \\
\text { hydrolyzed whey protein }\end{array}$ & $\begin{array}{l}\text { Blood pressure } \\
\text { reduction }\end{array}$ & USA \\
\hline Biopure GMP & $\kappa$-casein $\mathrm{f}(106-169)$ & $\begin{array}{l}\text { Prevention of dental } \\
\text { caries, influence the } \\
\text { clotting of blood, } \\
\text { protection against } \\
\text { viruses and bacteria }\end{array}$ & USA \\
\hline $\begin{array}{l}\text { Prodiet } \\
\text { F200/Lactium }\end{array}$ & $\begin{array}{l}\text { as1-casein (91-100) in } \\
\text { flavoured milk and } \\
\text { confectionery }\end{array}$ & $\begin{array}{l}\text { Reduction of stress } \\
\text { effects }\end{array}$ & France \\
\hline Festivo & $\begin{array}{l}\text { as1-casein (1-9), as1- } \\
\text { casein (1-7), as1-casein } \\
(1-6) \text { from fermented } \\
\text { low-fat hard cheese }\end{array}$ & $\begin{array}{l}\text { No health claim as } \\
\text { yet }\end{array}$ & Finland \\
\hline Capolac & $\begin{array}{l}\text { Casein-derived } \\
\text { peptide }\end{array}$ & $\begin{array}{l}\text { Helps mineral } \\
\text { absorption }\end{array}$ & Sweden \\
\hline Peptopro & $\begin{array}{l}\text { Casein-derived } \\
\text { peptide }\end{array}$ & $\begin{array}{l}\text { Improves athletic } \\
\text { performance and } \\
\text { muscle recovery }\end{array}$ & Netherlands \\
\hline Vivinal Alpha & $\begin{array}{l}\text { Whey derived } \\
\text { peptide }\end{array}$ & $\begin{array}{l}\text { Aids relaxation and } \\
\text { sleep }\end{array}$ & Netherlands \\
\hline
\end{tabular}


Table.2 Antioxidant peptides identified from casein

\begin{tabular}{|c|c|c|c|}
\hline Protein & Treatment & Fragment & Reference \\
\hline Casein & Pepsin & $\begin{array}{l}\alpha s-1 \text {-casein } f(144- \\
149)\end{array}$ & Suetsuna et al., 2000 \\
\hline Casein & Trypsin & $\begin{array}{l}\beta \text {-casein } \mathrm{f}(98-105) \\
\beta \text {-casein } \mathrm{f}(177-183) \\
\beta \text {-casein } \mathrm{f}(169-176) \\
\beta \text {-casein } \mathrm{f}(170-176)\end{array}$ & Rival et al., 2001 \\
\hline Casein & Papain & $\begin{array}{l}\text { as2-casein } f(123- \\
129) \\
\kappa \text {-casein } f(61-65) \\
\kappa \text {-casein } f(61-66)\end{array}$ & Bezerra et al., 2013 \\
\hline Casein & Pepsin & $\begin{array}{l}\text { as2-casein } \quad \mathrm{f}(174- \\
181) \\
\text { as2-casein } \\
208) \\
\kappa \text {-casein } \mathrm{f}(28-30) \\
\kappa \text {-casein } \mathrm{f}(30-32)\end{array}$ & $\begin{array}{l}\text { Lopez-Exposito et } \\
\text { al., } 2007\end{array}$ \\
\hline Casein & $\begin{array}{l}\text { Fermentation with } \\
\text { Lactobacillus } \\
\text { delbrueckii } \\
\text { subsp. bulgaricus }\end{array}$ & $\kappa$-casein $f(96-106)$ & Kudoh et al., 2001 \\
\hline
\end{tabular}

\section{Antimicrobial activity}

Antimicrobial peptides are encrypted within the parent protein and are inactive, upon hydrolysis, it becomes biologically active and shows positive health impact. Anti-microbial peptides are very essential for newborn babies because these are vulnerable to a broad spectrum of pathogenic microorganisms mainly present at mucosal surfaces like small intestine and lungs. It is reported that antimicrobial effect of milk is accredited by both immunoglobulins and non-immunoglobulin proteins like lysozymes, lactoferrin, lactoperoxidase system and peptides (Jabbari et al., 2012). Cationic antimicrobial peptides interact with the anionic component of teichoic acid and lipopolysaccharides (LPS) respectively, in gram-positive and gramnegative bacteria (Hancock, 1997) resulting in neutralization of the charge on the microbial surface, leads to disruption of a cellular envelope, and increases the permeability of cell (Oren, 1999). Sometimes, antimicrobial peptides lead to the formation of pores in the cell envelope leading to leakage of cell contents and ultimately resulting in cell death (He et al., 1996). Antimicrobial peptides damage the microbial cell membrane by electrostatic interaction, inhibiting protein, DNA, and RNA synthesis, or interacting with intracellular targets (Bahar and Ren, 2013). Lopez-Exposito et al., (2007) reported that peptic hydrolysate of ovine as2-casein and bovine $\kappa$-casein showed antimicrobial effect against Escherichia coli and Listeria innocua. Recio and Visser (1999) studied the antimicrobial activity of two fractions $\mathrm{f}(164-$ $179)$ and $f(183-207)$ isolated from peptic hydrolysate of bovine as2-casein. These peptides exhibited minimum inhibitory concentration between 8-99 $\mu \mathrm{M}$. Antimicrobial activity is determined, by the presence and position of positive charge, 
hydrophobic, and the basic amino acid residues in peptides. Bougherra et al., (2017) reported a peptide from as2-casein (SSSEESII) that showed antimicrobial activity against Listeria innocua, Micrococcus luteus, Escherichia coli, and Salmonella enteritidis due to the presence of hydrophobic amino acid in sequence, by using agar diffusion and micro-dilution method. Kumar et al., (2016) investigated the antimicrobial activity of camel casein hydrolyzed with alcalase, $\alpha$-chymotrypsin, and pepsin using a well diffusion method against Listeria monocytogenes, Staphylococcus aureus, Escherichia coli, and Bacillus cereus. Benkerroum et al., (2004) reported antimicrobial activity of camel milk against pathogenic strains of Escherichia coli, Listeria monocytogenes, and Bacillus cereus. Pepsin hydrolysis of ovine $\alpha \mathrm{S} 2-\mathrm{CN}$ resulted in production of four anti-microbial peptide fragments like f165-170, f165-181, f184-208 and f203-208. These fragments are potent anti-bacterial against Gram negative bacteria. Furthermore, among all these fragment f165181 showed highest anti-microbial activity while fragment f203-208 also showed antioxidant and anti-hypertensive activity.

In conclusion, casein is a rich source of bioactive peptides that exhibites a multifunctional role. These bioactive peptides get active only after releasing from native protein. So more research is required in the direction of how these peptides can retain their sequence during gastrointestinal digestion, enter into the bloodstream, and act on the target site. There is an urgent need to focus on developing novel facilities including advanced proteomics approaches, recombinant enzyme technologies and microbial fermentation, to study the various impacts of bioactive peptides on expression of genes and also to optimize the nutritional and health effects of these compounds.

\section{References}

Ahmed, A.S., El-Bassiony, T., Elmalt, L.M., \& Ibrahim, H.R. 2015. Identification of potent antioxidant bioactive peptides from goat milk proteins. Food Res. Int. 74: 8088.

Ali, H., Houghton, P.J. and Soumyanath, A. 2006. $\alpha$-Amylase inhibitory activity of some Malaysian plants used to treat diabetes; with particular reference to Phyllanthus amarus. J. Ethnopharmacol. 107(3): 449-455.

Ashar, M.N. and Chand, R. 2004. Antihypertensive peptides purified from milks fermented with Lactobacillus delbrueckii ssp. bulgaricus. Milchwissenschaft. 59(1-2): 14-17.

Bahar, A. and Ren, D. 2013. Antimicrobial peptides. Pharm. 6(12): 1543-1575.

Benkerroum, N., Mekkaoui, M., Bennani, N. and Hidane, K. 2004. Antimicrobial activity of camel's milk against pathogenic strains of Escherichia coli and Listeria monocytogenes. Int. J. Dairy Tech. 57(1): 39-43.

Bezerra, V.S., Campos, J.F., Silva, R.A.D., Porto, T.S., Lima Filho, J.L.D. and Porto, A.L.F. 2013. Biotechnological richness of the northeastern semi-arid region: antioxidant activity of casein hydrolysates from Moxoto goat milk (Capra hircus Linnaeus, 1758) obtained by papain action. Food Sci. Technol. 33(3): 513520.

Bode, W. (2006). Structure and interaction modes of thrombin. Blood Cells, Molecules, and Diseases. 36(2), 122-130.

Bougherra, F., Dilmi-Bouras, A., Balti, R., Przybylski, R., Adoui, F., Elhameur, H., Chevalier, M., Flahaut, C., Dhulster, P. and Naima, N. 2017. Antibacterial activity of new peptide from bovine casein hydrolyzed by a serine metalloprotease of Lactococcus lactis subsp lactis BR16. J. Funct. Foods. 32: 112-122. 
Boye, J., Wijesinha-Bettoni, R. and Burlingame, B. 2012. Protein quality evaluation twenty years after the introduction of the protein digestibility corrected amino acid score method. Br. J. Nutr. 108(S2): S183-S211.

Cadee, J.A., Chang, C.Y., Chen, C.W., Huang, C.N., Chen, S.L. and Wang, C.K. 2007. Bovine casein hydrolysate (C12 peptide) reduces blood pressure in prehypertensive subjects. Am. J. Hypertens. 20(1): 1-5.

Chen, H.M., Muramoto, K., Yamauchi, F. and Nokihara, K. 1996. Antioxidant activity of designed peptides based on the antioxidative peptide isolated from digests of a soybean protein. J. Agric. Food Chem. 44(9): 2619-2623.

Chiba, H., Tani, F., \& Yoshikawa, M. (1989). Opioid antagonist peptides derived from k-casein. J. Dairy Res, 56(3), 363-366.

Davie, E. W., Fujikawa, K., \& Kisiel, W. (1991). The coagulation cascade: initiation, maintenance, and regulation. Biochemistry, 30(43), 10363 10370.

Erdmann, K., Cheung, B. W., \& Schröder, H. (2008). The possible roles of food-derived bioactive peptides in reducing the risk of cardiovascular disease. J Nutr Biochem. 19(10), 643-654.

Fang, Y. Z., Yang, S., \& Wu, G. (2002). Free radicals, antioxidants, and nutrition. Nutr. 18(10), 872-879.

FitzGerald, R. J. (1998). Potential uses of caseinophosphopeptides. Int. Dairy J. 8(56), 451-457.

FitzGerald, R.J., Murray, B.A. and Walsh, D.J. 2004. Hypotensive peptides from milk proteins. J. Nutr. 134(4): 980-988.

Ferranti, P., Traisci, M.V., Picariello, G., Nasi, A., Boschi, V., Siervo, M., Falconi, C., Chianese, L. and Addeo, F. 2004. Casein proteolysis in human milk: tracing the pattern of casein breakdown and the formation of potential bioactive peptides. J. Dairy Res. 71(1): 74-87.

Ferreira, I.M.P.L.V.O., Pinho, O., Mota, M.V., Tavares, P., Pereira, A., Goncalves, M.P., Torres, D., Rocha, C. and Teixeira, J.A.
2007. Preparation of ingredients containing an ACE-inhibitory peptide by tryptic hydrolysis of whey protein concentrates. Int. Dairy J. 17(5): 481-487.

Fox, P.F., Mcsweeny, P.L., and Paul, L. 1998. Dairy chemistry and biochemistry. No. 637 F6. $2^{\text {nd }}$ Edition. London: Blackie Academic and Professional.

Frenkel, K. (1992). Carcinogen-mediated oxidant formation and oxidative DNA damage. Pharma. \& therap. 53(1), 127166.

Fuglsang, A., Rattray, F.P., Nilsson, D., and Nyborg, N.C. 2003. Lactic acid bacteria: inhibition of angiotensin converting enzyme in vitro and in vivo. Antonie Van Leeuwenhoek. 83(1): 27-34.

Furie, B., \& Furie, B. C. (1988). The molecular basis of blood coagulation. Cell. 53(4), 505-518.

Lalita Garg, Geeta Chauhan, SK Mendiratta, Kamal Kumar. In vitro assessment of ACE inhibitory activity of A1 and A2 cow milk casein hydrolysate. J Entomol Zool Stud 2021;9(1):1575-1578. DOI: 10.22271/j.ento.2021.v9.i1v.8363

Ghamari, F., M Ghaffari, S., Salami, M., Moosavi-Movahedi, F., Farivar, F., Johari, A., A Saboury, A., M Chobert, J., Haertle, T. and A Moosavi-Movahedi, A. 2013. Synergic study of $\alpha$-glucosidase inhibitory action of aloin and its antioxidant activity with and without camel $\beta$-casein and its peptides. Protein Pept. Lett. 20(5): 607-612.

Griffiths, M.W. and Tellez, A.M. 2013. Lactobacillus helveticus: the proteolytic system. Front. Microbiol. 4: 30.

Hancock, R.E. $1997 . \quad$ Peptide antibiotics. Lancet 349(9049): 418-422.

Harvey, R., \& Ferrier, D. (2011). Glycolysis. Lippincott's Illustrated Reviews: Biochemistry. 5th. ed. Philadelphia: Lippincott Williams \& Wilkins, 2011b, 91-108.

Haug, A., Hostmark, A.T., and Harstad, O.M. 2007. Bovine milk in human nutrition-a review. Lipids Health Dis. 6(1): 25.

He, K., Ludtke, S.J., Heller, W.T. and Huang, 
H.W. 1996. Mechanism of alamethicin insertion into lipid bilayers. Biophys. J. 71(5): 2669-2679.

Hernandez-Ledesma, B., Amigo, L., Ramos, M. and Recio, I. 2004. Angiotensin converting enzyme inhibitory activity in commercial fermented products. Formation of peptides under simulated gastrointestinal digestion. J. Agric. Food Chem. 52(6): 1504-1510.

Hernandez-Ledesma, B., Amigo, L., Recio, I., and Bartolome, B. 2007. ACE-Inhibitory and radical-scavenging activity of peptides derived from $\beta$-Lactoglobulin $\mathrm{f}$ (19- 25). Interactions with ascorbic acid. J. Agric. Food Chem. 55(9): 33923397.

International Diabetes Federation. 2015. IDF Diabetes Atlas. Brussels,Belgium: International Diabetes Federation.

Irshad, I., Kanekanian, A., Peters, A., and Masud, T. 2015. Antioxidant activity of bioactive peptides derived from bovine casein hydrolysate fractions. J. Food Sci. Technol. 52(1): 231-239.

Jabbari, S., Hasani, R., Kafilzadeh, F., \& Janfeshan, S. (2012). Antimicrobial peptides from milk proteins: a prospectus. Ann Biol Res, 3, 5313-5318.

Jakubowicz, D. and Froy, O. 2013. Biochemical and metabolic mechanisms by which dietary whey protein may combat obesity and Type 2 diabetes. J. Nutr. Biochem. 24(1): $1-5$.

Jan, F., Kumar, S., and Jha, R. 2016. Effect of boiling on the antidiabetic property of enzyme treated sheep milk casein. Vet. World. 9(10): 1152.

Karaki, H., Doi, K., Sugano, S., Uchiwa, H., Sugai, R., Murakami, U. and Takemoto, S. 1990. Antihypertensive effect of tryptic hydrolysate of milk casein in spontaneously hypertensive rats. Comp. Biochem. Physiol. C Toxicol. Pharmacol. 96(2): 367-371.

Kawasaki, Y., Isoda, H., Tanimoto, M., Dosako, S. I., Idota, T., \& Ahiko, K. (1992). Inhibition by lactoferrin and $\kappa$-casein glycomacropeptide of binding of cholera toxin to its receptor. Biosci. Biotechnol. Biochem. 56(2), 195-198.

Kilara, A. and Panyam, D. 2003. Peptides from milk proteins and their properties. Crit. Rev. Food Sci. Nutr. 43(6): 607-633.

Kitts, D.D. and Weiler, K. 2003. Bioactive proteins and peptides from food sources. Applications of bioprocesses used in isolation and recovery. Curr. Pharm. Des. 9(16): 1309-1323.

Korhonen, H. and Pihlanto, A. 2003. Bioactive peptides: novel applications for milk proteins. Appl. Biotechnol. Food Sci. Policy. 1: 133-144.

Korhonen, H. and Pihlanto, A. 2006. Bioactive peptides: production and functionality. Int. Dairy J. 16(9): 945-960.

Kudoh, Y., Matsuda, S., Igoshi, K. and Oki, T. 2001. Antioxidative peptide from milk fermented with Lactobacillus delbrueckii subsp. bulgaricus IFO13953. J. Jap. Soc. Food Sci. Tech. 48: 44-50

Kumar, D., Chatli, M.K., Singh, R., Mehta, N., and Kumar, P. 2016. Enzymatic hydrolysis of camel milk casein and its antioxidant properties. Dairy Sci. Tech. 96(3): 391-404.

Kwon, Y.I.I., Vattem, D.A. and Shetty, K. 2006. Evaluation of clonal herbs of Lamiaceae species for management of diabetes and hypertension. Asia Pac. J. Clin. Nutr. 15(1): 107.

Lahov, E., \& Regelson, W. (1996). Antibacterial and immunostimulating casein-derived substances from milk: casecidin, isracidin peptides. Food Chem. Toxico. 34(1), 131-145.

Lopez-Exposito, I., Quiros, A., Amigo, L. and Recio, I. 2007. Casein hydrolysates as a source of antimicrobial, antioxidant and antihypertensive peptides. Le Lait. 87(45): 241-249.

Loukas, S., Varoucha, D., Zioudrou, C., Streaty, R. A., \& Klee, W. A. (1983). Opioid activities and structures of. alpha.-caseinderived exorphins. Biochemistry, 22(19), 4567-4573.

Mao, X.Y., Ni, J.R., Sun, W.L., Hao, P.P. and Fan, L. 2007. Value-added utilization of 
yak milk casein for the production of angiotensin-I-converting enzyme inhibitory peptides. Food Chem. 103(4): 1282-1287.

Maruyama, S. and Suzuki, H. 1982. A peptide inhibitor of angiotensin I converting enzyme in the tryptic hydrolysate of casein. Agric. Biol. Chem. 46(5): 13931394.

Matsui, T., Yoshimoto, C., Osajima, K., Oki, T. and Osajima, Y. 1996. In vitro survey of $\alpha$-glucosidase inhibitory food components. Biosci. Biotechnol. Biochem. 60(12): 2019-2022.

Meisel, H. 2004. Multifunctional peptides encrypted in milk proteins. Biofactors. 21(1-4): 55-61.

Miguel, M., Contreras, M. M., Recio, I. And Aleixandre, A. 2009. ACE-inhibitory and antihypertensive properties of a bovine casein hydrolysate. Food Chem. 112(1): 211-214.

Moller, N. P., Scholz-Ahrens, K. E., Roos, N. and Schrezenmeir, J. 2008. Bioactive peptides and proteins from foods: indication for health effects. Eur. J. Nutr. 47(4): 171-182.

Nakamura, Y., Yamamoto, N., Sakai, K. and Takano, T. 1995. Antihypertensive effect of sour milk and peptides isolated from it that are inhibitors to angiotensin Iconverting enzyme. J. Dairy Sci. 78(6): 1253-1257.

Nongonierma, A.B. and FitzGerald, R.J. 2013. Dipeptidyl peptidase IV inhibitory and antioxidative properties of milk proteinderived dipeptides and hydrolysates. Peptides. 39: 157-163.

Ondetti, M.A., Rubin, B. and Cushman, D.W. 1977. Design of specific inhibitors of angiotensin-converting enzyme: new class of orally active antihypertensive agents. Sci. 196(4288): 441-444.

Ondetti, M.A. and Cushman, D.W. 1982. Enzymes of the renin-angiotensin system and their inhibitors. Annu. Rev. Biochem. 51(1): 283-308.

Oren, A. 1999. Bioenergetic aspects of halophilism. Microbiol. Mol. Biol. Rev. 63(2): 334-348.

Oshima, G., Shimabukuro, H. and Nagasawa, K. 1979. Peptide inhibitors of angiotensin I-converting enzyme in digests of gelatin by bacterial collagenase. Biochim. Biophys. Acta. 566(1): 128-137.

Otte, J., Shalaby, S.M., Zakora, M. and Nielsen, M.S. 2007. Fractionation and identification of ACE-inhibitory peptides from $\alpha$-lactalbumin and $\beta$-casein produced by thermolysin-catalysed hydrolysis. Int. Dairy J. 17(12): 14601472.

Petrat-Melin, B., Andersen, P., Rasmussen, J.T., Poulsen, N.A., Larsen, L.B. and Young, J.F. 2015. In vitro digestion of purified $\beta$ casein variants A1, A2, B, and I: Effects on antioxidant and angiotensin-converting enzyme inhibitory capacity. J. Dairy Sci. 98(1): 15-26.

Pinto, M.D. S., Kwon, Y.I., Apostolidis, E., Lajolo, F. ., Genovese, M.I. and Shetty, K. 2009. Potential of Ginkgo biloba L. leaves in the management of hyperglycemia and hypertension using in vitro models. Bioresour. Tech. 100(24): 6599-6609.

Qian, Z. Y., Jollès, P., Migliore-Samour, D., Schoentgen, F., \& Fiat, A. M. (1995). Sheep $\kappa$-casein peptides inhibit platelet aggregation. Biochimica et Biophysica Acta (BBA)-General Subjects, 1244(2-3), 411-417.

Ramachandran, P. and Srividya, N. 2014. In vitro antidiabetic activity and in vivo post prandial glycemic response of aloe gel enriched curd. Int. J. Food Sci. Nutr. 3(1): 38-46.

Recio, I. and Visser, S. 1999. Identification of two distinct antibacterial domains within the sequence of bovine $\alpha$ s2casein. Biochim. Biophys. Acta. 1428(23): 314-326.

Rival, S.G., Boeriu, C.G. and Wichers, H.J. 2001. Caseins and casein hydrolysates. 2. Antioxidative properties and relevance to lipoxygenase inhibition. J. Agric. Food Chem. 49(1): 295-302. 
Salami, M., Moosavi-Movahedi, A. A., Moosavi-Movahedi, F., Ehsani, M. R., Yousefi, R., Farhadi, M. and Haertle, T. 2011. Biological activity of camel milk casein following enzymatic digestion. J. Dairy Res. 78(4): 471-478.

Schaafsma, G. 2000. The protein digestibilitycorrected amino acid score. J. Dairy Res. 130(7): 1865-1867.

Schlimme, E., \& Meisel, H. (1995). Bioactive peptides derived from milk proteins. Structural, physiological and analytical aspects. Food/Nahrung, 39(1), 1-20.

Sekiya, S., Kobayashi, Y., Kita, E., Imamura, Y. and Toyama, S. 1992. Antihypertensive effects of tryptic hydrolysate of casein on normotensive and hypertensive volunteers. J. Jpn. Soc. Nutr. Food sci. 45: 513-517

Severin, S. and Wenshui, X. 2005. Milk biologically active components as nutraceuticals. Crit. Rev. Food Sci. Nutr. 45(7-8): 645-656.

Shahidi, F., \& Zhong, Y. (2008). Bioactive peptides. Journal of AOAC international, 91(4), 914-931.

Shanmugam, V.P., Kapila, S., Sonfack, T.K. and Kapila, R. 2015. Antioxidative peptide derived from enzymatic digestion of buffalo casein. Int. Dairy J. 42: 1-5.

Shimizu, M. and Ok Son, D. 2007. Foodderived peptides and intestinal functions. Curr. Pharm. Des. 13(9): 885-895.

Suetsuna, K., Ukeda, H. and Ochi, H. 2000. Isolation and characterization of free radical scavenging activities peptides derived from casein. J. Nutr. Biochem. 11(3): 128-131.

Suetsuna, K. and Chen, J.R. 2002. Isolation and characterization of peptides with antioxidant activity derived from wheat gluten. Food Sci. Tech. Res. 8(3):227230.

Sugai, R. 1998. ACE inhibitors and functional foods (Angiotensin-I Converting Enzyme). Int. Dairy Fed.

Sultan, S., Huma, N., Butt, M.S., Aleem, M. and Abbas, M. 2018. Therapeutic potential of dairy bioactive peptides: A contemporary perspective. Crit. Rev. Food Sci. Nutr. 58(1): 105-115.

Szwajkowska, M., Wolanciuk, A., Barłowska, J., Krol, J. and Litwinczuk, Z. 2011. Bovine milk proteins as the source of bioactive peptides influencing the consumers immune system-a review. Anim. Sci. Pap. Rep. 29(4): 269280.

Teschemacher, H. (2003). Opioid receptor ligands derived from food proteins. Current pharma. Design. 9(16), 1331-1344.

Tu, M., Feng, L., Wang, Z., Qiao, M., Shahidi, F., Lu, W., \& Du, M. (2017). Sequence analysis and molecular docking of antithrombotic peptides from casein hydrolysate by trypsin digestion. J Func. Foods, 32, 313-323.

World Health Organization (WHO). 2016. The mysteries of type 2 diabetes in developing countries. Bull World Health Organ. 94: 241-242.

$\mathrm{Xu}$, R. J. (1998). Bioactive peptides in milk and their biological and health implications. Food Reviews International, 14(1), 1-16.

Yamamoto, N., Maeno, M. and Takano, T. 1999. Purification and characterization of an antihypertensive peptide from a yogurt-like product fermented by Lactobacillus helveticus CPN4. J. Dairy Sci. 82(7): 1388-1393.

\section{How to cite this article:}

Lalita Garg and Kamal Kumar. 2021. Emerging Trend in Therapeutic Potential of Casein Derived Bioactive Peptides. Int.J.Curr.Microbiol.App.Sci. 10(02): 3094-3106. doi: https://doi.org/10.20546/ijcmas.2021.1002.338 